\title{
HUBUNGAN PENGETAHUAN IBU TENTANG IMUNISASI DASAR DENGAN KELENGKAPAN IMUNISASI DASAR DI WILAYAH KERJA PUSKESMAS LARANGAN UTARA KOTA TANGERANG
}

\author{
${ }^{1}$ Putri Handayani Setyaningsih, ${ }^{2}$ Erna Wulan Dari \\ Program Studi D3 Kebidanan STIKes Widya Dharma Husada Tangerang, \\ ${ }^{1}$ Email : putri_yupi87@yahoo.com
}

\begin{abstract}
ABSTRAK
Latar Belakang: Imunisasi merupakan salah satu cara pencegahan penyakit menular khususnya penyakit yang dicegah dengan imunisasi yang diberikan tidak hanya anak kepada sejak bayi hingga remaja tetapi juga pada dewasa. Menurut WHO (World Health Organization), program imunisasi di Indonesia memiliki tujuan untuk menurunkan angka kejadian penyakit dan angka kematian akibat penyakit syang dapat dicegah dengan imunisasi. Kementrian Kesehatan RI menunjukkan cakupan status imunisasi dasar lengkap (IDL) pada anak (usia 0-12 bulan) menurun dari 59,2\% menjadi 57,9\%, dan anak yang di imunisasi tapi tidak lengkap meningkat dari $32,1 \%$ menjadi $32,9 \%$ pada periode yang sama. Tujuan Penelitian: Tujuan dari penelitian ini adalah untuk mengetahui hubungan pengetahuan ibu tentang imunisasi dasar dengan kelengkapan imunisasi dasar di wilayah Kerja Puskesmas Larangan Utara Kota Tangerang. Metode Penelitian: Penelitian ini menggunakan jenis penelitian deskriptif korelasi dengan pendekatan cross sectional dengan $\alpha=10 \%$. Pengambilan data dilakukan pada 74 responden di Wilayah Puskesmas Larangan Utara Kota Tangerang pada bulan Mei 2019 dengan menggunakan kuesioner dan analisis data menggunakan Kendall's Tau. Hasil dan Kesimpulan: Ibu yang memiliki pengetahuan tentang imunisasi dasar yang cukup sebesar 51,3\% dan kelengkapan imunisasi sebesar 76,9\%. Hasil analisis didapatkan bahwa ada hubungan antara pengetahuan ibu dengan kelengkapan imunisasi dasar $(p=0,442)$ Saran: Hasil penelitian ini diharapkan dapat menjadi pertimbangan bagi instansi kesehatan agar dapat melakukan pembinaan guna meningkatkan pengetahuan serta kesadaran ibu-ibu untuk mengimunisasikan anaknya.
\end{abstract}

Kata Kunci : Pengetahuan, Imunisasi Dasar Lengkap, Kelengkapan Imunisasi Dasar

\begin{abstract}
Background: Immunization is one way to prevent infectious diseases, especially diseases that are prevented by immunization, which are given not only to children from infancy to adolescence but also in adults. According to the WHO (World Health Organization), immunization programs in Indonesia have a goal to reduce the incidence of disease and mortality due to diseases that can be prevented by immunization. The Indonesian Ministry of Health shows that complete basic immunization status (IDL) coverage for children (ages 0-12 months) decreased from $59.2 \%$ to $57.9 \%$, and immunized but incomplete children increased from $32.1 \%$ to $32,9 \%$ in the same period. Research Objectives: The purpose of this study was to determine the relationship between maternal knowledge about basic immunization and the completeness of basic immunizations in the Larangan Utara Health Center area of Tangerang City. Research Methods: This study used a descriptive correlation research with a cross sectional approach with $\alpha=10 \%$. Data collection was carried out on 74 respondents in the Larangan Utara Community Health Center in Kota Tangerang in May 2019 using a questionnaire and data analysis using the Kendall's Tau. Results and Conclusions: Mothers who have sufficient knowledge of basic immunization amounted to $51.3 \%$ and complete immunization was $76.9 \%$. The results of the analysis show that there is a relationship between maternal knowledge and completeness of basic immunization ( $p=0.442)$ Suggestion: The results of this study are expected to be a consideration for health agencies to be able to provide guidance to increase knowledge and awareness of mothers to immunize their children.
\end{abstract}

Keywords : Knowledge, Complete Basic Immunization, Basic Immunization Completion 


\section{PENDAHULUAN}

Kemajuan suatu bangsa perlu adanya penerus bangsa yang sehat, yang perlu di pupuk dari usia bayi, anak-anak dan remaja yang menjadi salah satu upaya untuk menyelamatkan anak bangsa salah satunya dengan imunisasi. Imunisasi berasal dari kata "imun" yang berarti kebal atau resisten. Imunisasi adalah cara untuk meningkatkan kekebalan seseorang terhadap suatu penyakit, sehingga bila kelak terpajan pada penyakit tersebut ia tidak menjadi sakit (Ranuh, 2011).

Dan menurut Kemenkes (2016) mengatakan Imunisasi adalah suatu upaya untuk menimbulkan/meningkatkan kekebalan seseorang secara aktif terhadap suatu penyakit, sehingga bila suatu saat penyakit itu menyerang tidak akan sakit atau hanya mengalami sakit ringan. Sedangkan menurut Depkes (2013) Imunisasi merupakan salah satu cara pencegahan penyakit menular khususnya penyakit yang dapat dicegah dengan imunisasi yang diberikan tidak hanya kepada sejak bayi hingga remaja tetapi juga pada dewasa.

Cakupan imunisasi di Indonesia dalam lima tahun terakhir tidak mengalami perkembangan yang signifikan. Hasil Riset Kesehatan Dasar 2018 Kementrian
Kesehatan RI menunjukkan cakupan status imunisasi dasar lengkap (IDL) pada anak (usia 0-12 bulan) menurun dari 59,2\% menjadi 57,9\% , dan anak yang di imunisasi tapi tidak lengkap meningkat dari $32,1 \%$ menjadi $32,9 \%$ pada periode yang sama. Angka imunisasi dasar lengkap anak di pedesaan lebih rendah $(53,8 \%)$ dibandingkan anak-anak di perkotaan (61,5\%). Dua kondisi tersebut cukup mengkhawatirkan untuk masa depan kesehatan anak-anak. Untuk status kelengkapan imunisasi pada anak di provinsi Banten pada tahun 2013 sebanyak $45,8 \%$. Sedangkan presentase data imunisasi di Kota Tangerang di dapatkan hasil cakupan 88,3\% (Kemenkes, 2016).

Imunisasi sangat dibutuhkan dalam upaya pencegahan penyakit. Hal ini sesuai dengan peraturan menteri kesehatan Republik Indonesia nomor 42 tahun 2013. Peraturan tersebut menyatakan tentang penyelenggaraan imunisasi bahwa untuk meningkatkan derajat kesehatan masyarakat dan mempertahankan status kesehatan seluruh rakyat diperlukan tindakan imunisasi sebagai tindakan preventif. Imunisasi merupakan salah satu tindakan pencegahan penyebaran penyakit ke wilayah lain yang terbukti sangat cost effective. 
Menurut Undang-Undang Nomor 34 tahun 2009 tentang Kesehatan, Imunisasi merupakan salah satu upaya untuk mecegah terjadinya penyakit menular yang merupakan salah satu kegiatan prioritas Kementrian Kesehatan sebagai salah satu bentuk nyata komitmen pemerintah untuk mencapai Sustainable Development Goals (SDGs) khususnya untuk menurunkan angka kematian pada anak (Kemenkes, 2017).

Menurut WHO (World Health Organization), program imunisasi di Indonesia memiliki tujuan untuk menurunkan angka kejadian penyakit dan angka kematian akibat penyakit yang dapat dicegah dengan imunisasi (PD3I). Pada saat ini penyakit-penyakit tersebut adalah disentri, tetanus, batu rejan (pertusis), cacar (measles), polio, dan tuberculosis.

Imunisasi BCG (Bacille CalmetteGuerin) merupakan imunisasi yang digunakan untuk mencegah terjadinya penyakit TBC yang berat sebab terjadinya penyakit TBC yang berat seperti TBC pada selaput otak. TBC milier (pada seluruh lapang paru) atau TBC tulang. Pemberian diberikan satu kali, rentang waktu dari 0 bulan- 2 bulan. Dosis 0,05 ml untuk bayi kurang dari 1 tahun dan 0,1 ml untuk anak > 1 tahun. Vaksinasi BCG diberikan secara intrakutan di daerah lengan kanan atas pada insersio M.deltoideus sesuai anjuran WHO, tidak di tempat lain (bokong atau paha).

Imunisasi hepatitis B diberikan untuk melindungi bayi dari penyakit hepatitis B, yaitu penyakit infeksi virus berpotensi fatal yang dapat menyebabkan sirosis atau kanker hati. Pemberian diberikan tiga kali, saat usia baru lahir, 1 bulan, dan 6 bulan. Jumlah dosis vaksin yang diberikan, interval di antara dosis, genetika, prematuritas, dan kondisi medis yang mendasari memengaruhi imunogenisitas. Setelah dosis ketiga vaksin hepatitis B, lebih dari $95 \%$ anak serokonversi. Titer membaik dengan interval lebih panjang di antara dosis kedua dan ketiga sehingga rangkaian vaksin tidak perlu diulang tanpa memandang keterlambatan dosis. Imunisasi hepatitis B yang ke-1 diberikan sedini mungkin (dalam waktu 12 jam) setelah lahir, memngingat paling tidak 3,9\% ibu hamil mengidap hepatitis $\mathrm{B}$ aktif dengan resiko penularan kepada bayinya sebesar $45 \%$.

Vaksin Pentabio (DTP-Hb-Hib) adalah vaksin yang berfungsi untuk mencegah penyakit difteri, tetanus, pertusis, Hepatitis $\mathrm{B}$ dan radang selaput otak (meninginits) pada anak dibawah usia 5 tahun (balita). Sasaran imunisasi DTP-Hb-Hib merupakan imunisasi rutin yang diberikan kepada sasaran usia 0-11 bulan. Dosis pemberian 
imunisasi DTP-Hb-Hib adalah 0,5 ml dengan cara penyuntikan secara intramuskular pada paha anterolateral pada bayi dan di lengan kanan atas pada balita saat imunisasi lanjutan. Imunisasi lanjutan DTP-Hb-Hib dan campak diberikan kepada anak balita. Pemberian imunisasi DTP-HbHib merupakan pengganti imunisasi DTPHIB diberikan pada bayi sebanyak 3 dosis jadwalnya juga sama.

Imunisasi polio merupakan imunisasi yang digunakan untuk mencegah terjadinya penyakit poliomyelitis yang dapat menyebabkan kelumpuhan pada anak (Hidayat dalam Latumahina 2016). Efek samping dari vaksinasi ini sebagian kecil resipien dapat mengalami gejala pusing, diare ringan, dan nyeri otot. Vaksin polio pemberian diberikan empat kali, saat usia 0,2,4,6 bulan. Untuk imunisasi dasar (polio$2,3,4$ ) diberikan pada umur 2,4 , dan 6 bulan, interval antara dua imunisasi tidak kurang dari 4 minggu. Diulang sekali, antara usia 1,5-2 tahun.

Imunisasi MR (Measles, Rubella) merupakan imunisasi merupakan imunisasi yang digunakan dalam memberikan kekebalan terhadap penyakit campak (measles) dan campak jerman (rubella). Dalam imunisasi MR (Measles, Rubella), antigen yang di pakai adalah virus campak strain Edmonson yang dilemahkan, virus rubella strai RA 27/3, dan virus gondong.

Pengetahuan merupakan hasil dari tahu yang terjadi setelah orang melakukan pengindraan terhadap suatu objek tertentu, pengindraan terjadi melalui panca indra manusia yakni indra penglihatan, pendengaran, penciuman, rasa dan raba. Sebagian besar pengetahuan manusia diperoleh melalui mata dan telinga. Pengetahuan merupakan domain yang sangat dalam membentuk tindakan seseorang.

Berdasarkan penelitian yang dilakukan oleh Selina Heraris (2015) dengan judul "Hubungan Pengetahuan Ibu Tentang Imunisasi Dasar Terhadap Kelengkapan Imunisasi Dasar Pada Anak di Posyandu Wilayah Kerja Puskesmas Pembina Plaju Palembang" didapatkan hasil bahwa tingkat pengetahuan ibu tentang imunisasi dasar terhadap kelengkpan imunisasi dasar tidak memiliki hubungan.

Penelitian ini didukung oleh Muhammad Mijwad Luthfi, dkk (2014) dengan judul "Hubungan Tingkat Pengetahuan Ibu Tentang Imunisasi dengan Kelengkapan Imunisasi Dasar di Posyandu Mardi Rahayu Ngaliyan, Palem, Simo, Boyolali" didapatkan hasil bahwa ada hubungan antara tingkat pengetahuan ibu 
tentang imunisasi dengan kelengkapan imunisasi.

Berdasarkan latar belakang diatas, maka penulis ingin mengetahui "Hubungan Pengetahuan Ibu Tentang Imunisasi Dasar Dengan Kelengkapan Imunisasi Dasar" yang mana pengetahuan ibu akan imunisasi dasar masih sangat rendah di Indonesia dan salah satu nya di wilayah Tangerang, yang masih menjadi masalah kesehatan bagi dinas kesehatan yang harus menanggulangi masalah tersebut. Dan sebab itu, penulis tertarik untuk meneliti kasus imunisasi dasar di wilayah Puskesmas Larangan Utara Kota Tangerang.

\section{METODE PENELITIAN}

Penelitian ini menggunakan jenis penelitian deskriptif korelasi dengan pendekatan cross sectional, penelitian ini tujuan nya untuk menemukan ada atau tidaknya hubungan. Penelitian crosssectional adalah jenis penelitian yang menekankan waktu pengukuran/observasi data variabel independen dan dependen dinilai secara simultan pada suatu saat, jadi tidak ada tindak lanjut. Tidak semua subjek penelitian harus diobservasi pada hari atau pada waktu yang sama, akan tetapi baik variabel independen maupun variabel dependen dinilai hanya satu kali saja. Dengan studi ini, akan diperoleh peroleh prevalensi atau efek suatu fenomena (variabel dependen) dihubungkan dengan penyebab/variabel dependen (Nursalam dalam Nurhidayati, 2016).

Rancangan penelitian ini untuk mengidentifikasi hubungan pengetahuan ibu tentang imunisasi dasar dengan kelengkapan imunisasi dasar pada bayi di wilayah kerja Puskesmas Larangan Utara Kota Tangerang. Penelitian ini dilakukan hanya pada satu periode tertentu dan pengambilan sampel dilakukan dalam sekali waktu saja, tidak ada pengulangan dalam pengambilan data, dimana responden hanya mendapat satu kali kesempatan untuk menjadi responden.

Populasi dalam penelitian ini adalah ibu yang mempunyai anak atau bayi usia 0 bulan - 12 bulan. Dan populasi ibu yang mempunyai anak atau bayi usia 0 bulan 12 bulan adalah 285 responden.

Pengambilan sampel dalam penelitian ini adalah dengan teknik Accidental Sampling yaitu teknik penentuan sampel berdasarkan kebetulan, responden yang secara kebetulan/insidental bertemu dengan peneliti dapat digunakan sebagai sampel, bila dipandang orang yang kebetulan ditemui itu cocok sebagai sumber data . Besar sampel yang digunakan dalam penelitian ini adalah sesuai dengan ketentuan rumus besar sampel yang sesuai dengan rancangan penelitian yaitu 
menggunakan rumus slovin dan didapatkan jumlah sampel keseluruhan yang diambil untuk keperluan penelitian ini yaitu 74 responden ibu yang memiliki anak 0 bulan - 12 bulan. Prosedur pengumpulan data dilakukan dengan cara memberikan lembar

Pengolahan data menggunakan bantuan komputer dengan program SPSS versi 20 dengan lisensi tahun 2011. Data dianalisis secara univariat dan bivariat dan uji analisis yang digunakan dalam penelitian ini adalah uji Kendall's Tau.

\section{HASIL PENELITIAN Analisa Univariat.}

Tabel 1 Distribusi Frekuensi Responden Menurut Usia Ibu di Wilayah Puskesmas Larangan Utara Kota Tangerang Mei 2019

\begin{tabular}{ccc}
\hline Usia Ibu & Frekuensi & $\begin{array}{c}\text { Persentase } \\
(\mathbf{\%})\end{array}$ \\
\hline $\begin{array}{c}\text { Remaja Akhir (17-25 } \\
\text { tahun) }\end{array}$ & 5 & 6,8 \\
\hline $\begin{array}{c}\text { Dewasa Awal (26-35 } \\
\text { tahun) }\end{array}$ & 67 & 90,5 \\
\hline $\begin{array}{c}\text { Dewasa Akhir (36- } \\
\text { 45 tahun) }\end{array}$ & 2 & 2,7 \\
\hline Total & 74 & 100 \\
\hline
\end{tabular}

Berdasarkan tabel 1 menunjukkan bahwa hampir seluruh responden yang memiliki umur dewasa awal yaitu sebanyak 67 responden $(90,5 \%)$ dan sebagian kecil responden yang berumur dewasa akhir yaitu sebanyak 2 responden $(2,7 \%)$. pertanyaan persetujuan sebagai responden dan membagikan kuesioner pada ibu yang memiliki bayi 0 bulan - 12 bulan yang mengikuti posyandu di wilayah Kerja Puskesmas Larangan Utara Kota Tangerang.

Tabel 2 Distribusi Frekuensi Responden Menurut Jumlah Anak di Wilayah Puskesmas Larangan Utara Mei 2019

\begin{tabular}{|c|c|c|}
\hline $\begin{array}{c}\text { Jumlah } \\
\text { anak }\end{array}$ & Frekuensi & Persentase (\%) \\
\hline$\leq 2$ & 54 & 73,0 \\
\hline$>2$ & 20 & 27,0 \\
\hline Total & 74 & 100 \\
\hline
\end{tabular}

Berdasarkan tabel 2 menunjukkan bahwa sebagian besar responden dengan jumlah anak $\leq 2$ sebanyak 54 responden $(73,0 \%)$

Tabel 3 Distribusi Frekuensi Responden Menurut Pendidikan di Puskesmas Larangan Utara Mei 2019

\begin{tabular}{lcc}
\hline \multicolumn{1}{c}{ Pendidikan } & Frekuensi & Persentase (\%) \\
\hline SD & 4 & 5,4 \\
\hline SMP & 30 & 40,5 \\
\hline SMA & 37 & 50,0 \\
\hline $\begin{array}{l}\text { Perguruan } \\
\text { Tinggi }\end{array}$ & 3 & 4,1 \\
\hline Total & 74 & 100 \\
\hline
\end{tabular}

Berdasarkan tabel 3 menunjukkan bahwa sebagian responden yang tingkat pendidikan SMA sebanyak 37 responden $(50,0 \%)$ dan sebagian kecil responden yang tingkat pendidikan Perguruan Tinggi yaitu sebanyak 3 responden (4.1\%). 
Tabel 4 Distribusi Frekuensi Responden Menurut Pekerjaan di Wilayah Puskesmas Larangan Utara Mei 2019

\begin{tabular}{lcc}
\hline \multicolumn{1}{c}{ Pekerjaan } & Frekuensi & Presentase $\mathbf{( \% )}$ \\
\hline $\begin{array}{l}\text { Ibu Rumah } \\
\text { Tangga }\end{array}$ & 65 & 87,8 \\
\hline $\begin{array}{l}\text { Karyawan } \\
\text { Swasta }\end{array}$ & 2 & 2,7 \\
\hline Wirausaha & 7 & 9,5 \\
\hline Total & 74 & 100 \\
\hline
\end{tabular}

Berdasarkan tabel 4.4 menunjukkan bahwa hampir seluruh responden adalah ibu rumah tangga yaitu sebanyak 65 responden $(87,8 \%)$ dan sebagian kecil responden adalah karyawan swasta yaitu sebanyak 2 responden $(2,7 \%)$.

Tabel 5 Distribusi Frekuensi Responden Menurut Keterjangkauan di Wilayah Puskesmas Larangan Utara Mei 2019

\begin{tabular}{lcc}
\hline Keterjangkauan & Frekuensi & Persentase \\
\hline Terjangkau & 56 & 75,7 \\
\hline Tidak Terjangkau & 18 & 24,3 \\
& & \\
\hline Total & 74 & 100 \\
\hline
\end{tabular}

Berdasarkan tabel 5 menunjukkan bahwa sebagian besar responden adalah terjangkau ke fasilitas kesehatan yaitu sebanyak 56 responden $(75,7 \%)$.

Tabel 6 Distribusi Frekuensi Responden Menurut Pengetahuan di Wilayah Puskesmas Larangan Utara Mei 2019

\begin{tabular}{lcc}
\hline Pengetahuan & Frekuensi & $\begin{array}{c}\text { Persentase } \\
(\boldsymbol{\%})\end{array}$ \\
\hline Baik & 6 & 8,1 \\
\hline Cukup & 58 & 78,4 \\
\hline Kurang & 10 & 13,5 \\
\hline Total & 74 & 100 \\
\hline
\end{tabular}

Berdasarkan tabel 6 menunjukkan bahwa hampir seluruh responden memiliki pengetahuan yang cukup yaitu sebanyak 58 responden $(78,4 \%)$ dan sebagian kecil responden memiliki pengetahuan baik yaitu sebanyak 6 responden $(8,1 \%)$.

Tabel 7 Distribusi Frekuensi Responden Menurut Kelengkapan Imunisasi Dasar di Wilayah Puskesmas Larangan Utara Mei 2019

\begin{tabular}{lcc}
\hline $\begin{array}{c}\text { Kelengkapan } \\
\text { Imunisasi }\end{array}$ & Frekuensi & $\begin{array}{c}\text { Persentase } \\
(\boldsymbol{\%})\end{array}$ \\
\hline Lengkap & 23 & 31,1 \\
\hline Tidak Lengkap & 51 & 68,9 \\
\hline Total & 74 & 100 \\
\hline
\end{tabular}

Berdasarkan tabel 7 menunjukkan bahwa sebagian besar responden memiliki kelengkapan imunisasi tidak lengkap yaitu sebanyak 51 responden $(68,9 \%)$ dan hampir setengah responden memiliki kelengkapan imunisasi lengkap yaitu sebanyak 23 responden $(31,1 \%)$.

\section{Analisa Bivariat}

Tabel 8 Hasil Uji Korelasi Kendall's tau

\begin{tabular}{ccl}
\hline $\begin{array}{l}\text { Nilai } \\
\text { Signifikan }\end{array}$ & $\begin{array}{l}\text { Koefisien } \\
\text { Korelasi }\end{array}$ & \multicolumn{1}{c}{ Keterangan } \\
\hline 0,000 & 0,442 & Korelasi \\
& & Koefisien \\
& & Sedang, arah \\
& & korelasi positif \\
\hline
\end{tabular}

Berdasarkan tabel 8, menunjukan nilai signifikan sebesar 0,000 yang menunjuk kan bahwa korelasi bermakna atau hipotesis nol ditolak yang berarti ada hubungan 
antara pengetahuan ibu tentang imunisasi dasar terhadap kelengkapan imunisasi dasar di Wilayah Puskesmas Larangan Utara. Nilai Koefien Korelasi sebesar 0,442 yang menunjukkan kekuatan sedang dan arah korelasi positif, artinya semakin tinggi pengetahuan ibu maka semakin tinggi kelengkapan imunisasi.

\section{PEMBAHASAN}

\section{Karakteristik Responden}

\section{a. Usia Ibu}

Usia akan mempengaruhi terhadap daya tangkap dan pola pikir seseorang, semakin bertambah usia akan semakin berkembang pula daya tangkap dan pola pikirnya sehingga pengetahuan yang diperolehnya semakin membaik (Notoatmodjo dalam Nurhidayati, 2016).

Berdasarkan analisa yang didapat, usia ibu di wilayah Puskesmas Larangan Utara Kota Tangerang diperoleh hasil bahwa hampir seluruh responden yang memiliki umur dewasa awal yaitu sebanyak 67 responden $(90,5 \%)$ dan sebagian kecil responden yang berumur dewasa akhir yaitu sebanyak 2 responden $(2,7 \%)$. Hasil penelitian ini sesuai dengan penelitian Nurhidayati (2016) bahwa usia ibu mempengaruhi pengetahuan dan kemampuan dalam mengambil keputusan. Jadi semakin lanjut usia seseorang maka kemungkinan semakin meningkat pengetahuan dan pengalaman yang dimilikinya.

\section{b. Jumlah Anak}

Menurut Handayani dalam Nurhidayati (2016) Jumlah anak sebagai salah satu aspek demografi yang akan berpengaruh pada partisipasi masyarakat. Hal ini dapat terjadi karena seorang ibu mempunyai anak lebih dari satu biasanya ibu semakin berpengalaman dan sering memperoleh informasi tentang imunisasi.

Berdasarkan analisa yang didapat menurut jumlah anak di wilayah Puskesmas Larangan Utara Kota Tangerang diperoleh hasil bahwa sebagian besar responden dengan jumlah anak $\leq 2$ sebanyak 54 responden $(73,0 \%)$ dan hampir setengah responden dengan jumlah anak > 2 sebanyak 20 responden $(27,0 \%)$.

Hasil penelitian Nurhidayati (2016) bahwa rata-rata ibu yang memiliki anak lebih dari satu (multipara) sudah memiliki pengalaman yang lebih daripada ibu yang baru memiliki satu anak (primipara). Hal ini dikarenakan pengalaman yang diperoleh dari imunisasi anak yang sebelumnya sehingga ibu lebih mengetahui pentingnya kelengkapan imunisasi. 


\section{c. Pendidikan}

Pendidikan adalah proses seseorang mengembangkan kemampuan, sikap, dan bentuk-bentuk tingkah laku manusia didalam masyarakat tempat ia hidup, proses sosial, yakni orang dihadapkan pada pengaruh lingkungan yang terpilih dan terkontrol (khususnya yang datang dari sekolah), sehingga dia dapat memperoleh atau mengalami perkembangan kemampuan sosial, dan kemampuan individu yang optimal (Munib dalam Nurhidayati, 2016).

Berdasarkan analisa yang didapat menurut pendidikan ibu bahwa sebagian responden yang tingkat pendidikan SMA sebanyak 37 responden $(50,0 \%)$ dan sebagian kecil responden yang tingkat pendidikan Perguruan Tinggi yaitu sebanyak 3 responden (4.1\%).

Hasil penelitian ini didukung oleh penelitian Heraris (2015) yang menyatakan bahwa kelengkapan imunisasi dipengaruhi oleh tingkat pendidikan. Jadi pendidikan dapat mempengaruhi kelengkapan imunisasi.

\section{d. Pekerjaan}

Pekerjaan merupakan suatu kegiatan atau aktivitas seseorang untuk memperoleh penghasilan guna memenuhi kebutuhan hidupnya sehari-hari (Mulyanti, 2013).

Berdasarkan analisa yang di dapat bahwa hampir seluruh responden adalah ibu rumah tangga yaitu sebanyak 65 responden $(87,8 \%)$ dan sebagian kecil responden adalah karyawan swasta yaitu sebanyak 2 responden $(2,7 \%)$.

Hasil penelitian ini didukung oleh penelitian Nurhidayati (2016) yang menyatakan bahwa pekerjaan tidak mempengaruhi pengetahuan dari ibu, dapat dilihat dari hasil penelitian ini yang menunjukkan justru sebagian ibu yang berprofesi sebagai ibu rumah tangga memiliki pengetahuan yang baik dibandingkan ibu yang bekerja. Hal ini dikarenakan banyak ibu yang di rumah dilakukan pemantauan oleh petugas kesehatan saat adanya imunisasi.

\section{e. Keterjangkauan ke pelayanan kesehatan}

Kemudahan untuk mecapai pelayanan kesehatan ini antara lain ditentukan oleh adanya transportasi yang tersedia sehingga dapat memperkecil jarak tempuh, hal ini akan menimbulkan motivasi ibu untuk datang ketempat pelayanan imunisasi (Agustina, 2012).

Berdasarkan analisa yang di dapat bahwa sebagian besar responden adalah 
terjangkau ke fasilitas kesehatan yaitu sebanyak 56 responden $(75,7 \%)$ dan sebagian kecil responden adalah tidak terjangkau ke fasilitas kesehatan yaitu sebanyak 18 responden (24,3\%). Pada dasar nya pelayanan kesehatan harus terjangkau oleh masyarakat supaya meningkatnya derajat kesehatan. Pelayanan kesehatan yang terlalu jauh juga mengakibatkan masyarakat enggan untuk pergi berobat dan berakibat angka kesakitan semakin tinggi.

\section{f. Pengetahuan}

Menurut Notoatmodjo dalam Heraris (2015) pengetahuan adalah hasil dari "tahu" dan ini terjadi setelah orang mengadakan pengeinderaan terhadap suatu objek tertentu.

Berdasarkan analisa yang di dapat bahwa hampir seluruh responden memiliki pengetahuan yang cukup yaitu sebanyak 58 responden $(78,4 \%)$ dan sebagian kecil responden memiliki pengetahuan baik yaitu sebanyak 6 responden $(8,1 \%)$. Hasil penelitian ini didukung oleh penelitian Heraris (2015) yang menunjukkan tingkat pengetahuan rata-rata responden adalah kurang. Penyebab dari kurangnya tingkat pengetahuan ibu tentang imunisasi dasar adalah kurangnya ibu terpapar dengan materi yang ditanyakan pada kuesioner tentang pengetahuan ibu, sehingga ibu tidak dapat menjawab dengan benar.

\section{g. Kelengkapan}

Menurut Ali dalam Heraris (2015) faktor yang berhubungan dengan status kelengkapan imunisasi dasar adalah pengetahuan, pendidikan, usia ibu, sikap, status sosial ekonomi, serta opini orangtua. Berdasarkan analisa yang di dapat bahwa sebagian besar responden memiliki kelengkapan imunisasi tidak lengkap yaitu sebanyak 51 responden $(68,9 \%)$ dan hampir setengah responden memiliki kelengkapan imunisasi lengkap yaitu sebanyak 23 responden $(31,1 \%)$.

Hasil penelitian ini didukung oleh penelitian Heraris (2015) yang menyatakan bahwa alasan ibu tidak mengimunisasikan anaknya adalah tidak tahu jadwal imunisasi, takut efek samping, lupa, anak sakit, takut anak sakit, dan rumah jauh. Namun yang paling banyak ditemukakan adalah ibu tidak tahu jadwal imunisasi. Jadi kurangnya pengetahuan menyebabkan ibu tidak mengetahui jadwal imunisasi sehingga mempengaruhi status kelengkapan imunisasi anaknya.

2. Hubungan antara Pengetahuan Ibu tentang Imunisasi Dasar dengan Kelengkapan Imunisasi Dasar di Wilayah Puskemas Larangan Utara Kota Tangerang. 
Kurangnya pengetahuan ibu tentang imunisasi dapat dicegah dengan pemberian penyuluhan tentang imunisasi dasar lengkap kepada ibu. Penyuluhan tersebut harus mencakupi semua hal yang berhubungan tentang imunisasi terutama jadwal pemberian, frekuensi pemberian, dan fungsi dari masing-masing imunisasi tersebut, sehingga dapat meningkatkan pemahaman ibu tentang imunisasi dasar lengkap. Serta dengan pemahaman tersebut, ibu dapat membawa anaknya untuk diberikan imunisasi dasar lengkap (Dewi dalam Heraris, 2015).

Dari analisa yang didapat menunjuk kan nilai signifikan $(\mathrm{p}<0,05)$ sebesar 0,000 yang menunjukan bahwa korelasi bermakna atau hipotesis nol ditolak yang berarti ada hubungan antara pengetahuan ibu tentang imunisasi dasar terhadap kelengkapan imunisasi dasar di Wilayah Puskesmas Larangan Utara. Nilai Koefisien Korelasi sebesar 0,442 yang menunjukkan kekuatan sedang dan arah korelasi positif, artinya semakin tinggi pengetahuan ibu maka semakin tinggi kelengkapan imunisasi.

Penelitian ini juga diperkuat dengan penelitian yang dilakukan oleh Yusnidar (2012) di Kelurahan Sidorame Barat II Medan Perjuangan yang menyatakan bahwa dari 39 responden, yang didapatkan
20 orang $(51,3 \%)$ memiliki pengetahuan tentang imunisasi dasar yang cukup dan kelengkapan imunisasi dasar pada bayi sebagian besar adalah lengkap yaitu 30 orang $(76,9 \%)$, sehingga terdapat hubungan antara pengetahuan ibu tentang imunisasi dasar dengan kelengkapan imunisasi dasar. Faktor-faktor yang dapat mempengaruhi kelengkapan imunisasi antara lain pengetahuan, tingkat pendidikan, status pekerjaan, pendapatan keluarga, jarak dan keterjangkauan tempat pelayanan kesehatan, usia ibu dan jumlah anak.

\section{DAFTAR PUSTAKA}

Agustina. 2012. Pengetahuan dan Sikap Ibu Terhadap Pemberian Imunisasi Dasar Bayi di Wilayah Kerja Puskesmas Montasik Kabupaten Aceh Besar. [karya tulis ilmiah]. Banda Aceh : STIKes U'Budiah.

Dahlan, M.S. 2014. Statistik Untuk Kedokteran Dan Kesehatan. Jakarta: Salemba Medika.

Depkes. 2013. Tentang Imunisasi. www.depkes.go.id. Di akes tanggal 10 Mei 2019.

Hadianti, Nur. Dian. Dkk. 2015. Buku Ajar Imunisasi. Jakarta Selatan : Penerbit Pusat Pendidikan dan Pelatihan Tenaga Kesehatan.

Junaedi, M. 2019. Hubungan antara kecemasan dan konsep diri dengan kemandirian pada lansia Panti Werdha Bina Bhakti di Kampung Curug Babakan Setu Kota Tangerang Selatan. Skripsi. Tangerang Selatan. Stikes WDH. 
Latumahina, AA. 2016. Faktor-faktor Determinan Ketidaklengkapan Pemberian Imunisasi Kepada Bayi di Negeri Oma, Kecamatan Pulau Haruku, Maluku Tengah. Salatiga: Universitas Kristen Satya Wacana.

Luthfi, Mijwad. Dkk. 2014. Hubungan Tingkat Pengetahuan Ibu tentang Imunisasi dengan Kelengkapan Imunisasi Dasar. STIKES PKU Muhammadiyah Surakarta.

Maulani, Sulastri. Putri. 2017. Faktorfaktor yang Berhubungan Dengan Tingkat Pengetahuan Imunisasi TT Pada Ibu Hamil di Puskesmas Rawa Buntu Kota Tangerang Selatan. Tangerang Selatan: Stikes WDH.

Mulyani, dkk. 2018. Pengetahuan Ibu Tentang Kelengkapan Imunisasi Dasar Pada Bayi. [skripsi]. Jambi: FK Universitas Jambi.

Mulyanti, Y. 2013. Faktor-faktor Internal yang Berhubungan dengan Pemberian Imunisasi Dasar Balita Usia 1-5 Tahun di Wilayah Kerja Puskesmas Situgintung Tahun 2013. [skripsi]. Fakultas Kedokteran Dan Ilmu Kesehatan: UIN Syarif Hidayatullah.

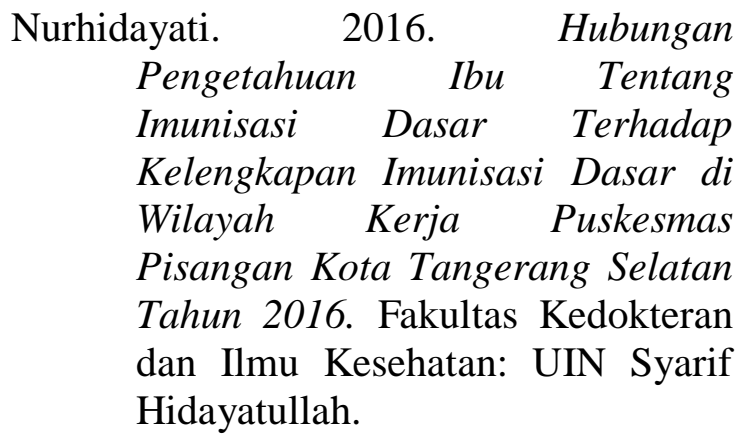

Notoatmodjo, S. 2014. Ilmu Perilaku Kesehatan. Jakarta: Rineka Cipta.

Peraturan Menteri Kesehatan Republik Indonesia. 2017. Tentang Penyelenggaraan Imunisasi. Diunduh tanggal 16 Mei 2019.
Pusat Data dan Informasi Kementrian Kesehatan RI. 2016. Situasi Imunisasi di Indonesia. www.depkes.go.id. Di unduh pada tanggal 10 Mei 2019.

Luriana. 2012. Faktor-faktor yang Berhubungan dengan Status Imunisasi Dasar pada Balita Umur 12-23 Bulan di Indonesia Tahun 2010. Depok: FKM UI.

Proverawati, dkk. 2010. Imunisasi dan Vaksinasi. Yogyakarta: Nuha Medika.

Ranuh, Gde. I.G.N. dkk. 2011. Pedoman Imunisasi Di Indonesia. Jakarta : Badan Penerbit Ikatan Dokter Indonesia.

Sari, Diana. Desti. 2018. Faktor-faktor Pada Ibu yang Berhubungan dengan Pemberian Imunisasi Dasar Bayi di Wilayah Kerja Puskesmas Korpri Kecamatan Sukarame Kota Bandar Lampung. [skripsi]. Lampung: Universitas Lampung.

Suzanne, W.B.S. 2011. A Parent's Decision on Imunization: Making The Right Choice. American Academy Of Pediatric.

Yulianto, A. 2018. Metodologi Penelitian Bisnis. Politeknik Negeri Malang: POLINEMA PRESS

Yusnidar, 2012. Hubungan Pengetahuan Ibu Tentang Imunisasi Dasar Dengan Kelengkapan Imunissi Dasar Pada Bayi Usia 0-12 Bulan Di Lingkungan IX Kelurahan Sidorame Barat II Medan Perjuangan. Medan. 